\title{
ANALISIS PENGARUH DEBT TO EQUITY RATIO, CURRENT RATIO DAN RETURN ON INVESTMENT TERHADAP DIVIDEN PAYOUT RATIO PADA PERUSAHAAN MAKANAN DAN MINUMAN YANG TERDAFTAR DI BURSA EFEK INDONESIA
}

\author{
Khoirul Huda \\ Salamatun Asakdiyah \\ Universitas Ahmad Dahlan
}

\begin{abstract}
ABSTRAK
This research was aimed to know whether there was an influence of Debt to Equity Ratio (DER), Current Ratio (CR), 'Return on Investment (ROI) towards Dividend Payout Ratio (DPR) in food and beverage companies listed in Indonesian Stock Exchange of 2010-2012 periods. Populations in this research were 18 food and beverage companies listed in Indonesian Stock Exchange of 2010-2012 periods. Sampling technique used a Purposive Sampling. It obtained 10 companies entered in the criteria. The analysis technique used a panel data regression and a hypothesis test using t-test with trust level of 5\%. Out of the three independent variables i.e. Debt to Equity Ratio (DER), Current Ratio (CR), Return On Investment (ROI), and Current Ratio (CR) significantly influenced Dividend Payout Ratio (DPR). R-square value was $38.5 \%$.
\end{abstract}

Keywords: Debt to Equity Ratio (DER), Current Ratio (CR), Return on Investment (ROI) and Dividend Payout Ratio.

\section{PENDAHULUAN}

Perkembangan ekonomi suatu negara dapat diukur dengan berbagai cara, salah satunya adalah dengan mengetahui tingkat perkembangan pasar modal dan perkembangan berbagai jenis industri pada negara tersebut. Pasar modal (capital market) merupakan pasar untuk berbagai instrumen keuangan jangka panjang dalam bentuk ekuitas dan hutang yang jatuh tempo lebih dari satu tahun. Dalam aktivitas di pasar modal, Para investor memiliki harapan dari investasi yang dilakukannya, yaitu yang berupa dividen dan capital gain.

Investor mempunyai tujuan utama dalam menanamkan dananya ke dalam perusahaan yaitu untuk mencari pendapatan atau tingkat kembalian investasi (return) baik berupa pendapatan dividen (dividend yield) maupun pendapatan dari selisih harga jual saham terhadap harga belinya (capital gain). Di sisi lain, perusahaan yang akan membagikan dividen dihadapkan pada berbagai macam pertimbangan antara lain: Perlunya menahan sebagian laba untuk re-investasi yang mungkin lebih menguntungkan, kebutuhan dana perusahaan, likuiditas perusahaan, sifat pemegang saham, target tertentu yang berhubungan dengan rasio pembayaran dividen dan faktor lain yang berhubungan dengan kebijakan dividen (Brigham dan Gapenski, 1996).

Dividen adalah distribusi yang bisa berbentuk kas, aktiva lain, surat atau bukti lain yang menyatakan hutang perusahaan kepada pemegang saham suatu perusahaan sebagai proporsi dari sejumlah saham yang dimiliki oleh 
pemilik (Jensen et al., 1992). Kebijakan dividen (dividend policy) adalah keputusan apakah laba yang diperoleh perusahaan akan dibagikan kepada pemegang saham sebagai dividen, atau akan ditahan dalam bentuk laba ditahan guna pembiayaan investasi dimasa mendatang (Sartono, 2010).

Bagi para investor yang bersedia mengambil resiko memiliki pandangan bahwa semakin tinggi tingkat resiko suatu perusahaan, akan semakin tinggi pula tingkat keuntungan yang diharapkan sebagai hasil atau imbalan terhadap resiko tersebut. Selanjutnya dividen yang diterima pada saat ini akan mempunyai nilai yang lebih tinggi dari pada capital gain yang akan diterima dimasa yang akan datang. Dengan demikian investor yang tidak bersedia berspekulasi akan lebih menyukai dividen dari pada capital gain (Prihantono, 2003).

Kebijakan dividen cenderung menjadi salah satu elemen yang paling stabil dan dapat diprediksi oleh perusahaan, dan sebagian besar perusahaan mulai membayar dividen setelah mereka mencapai tahap kematangan bisnis dán ketika tidak ada lagi kesempatan investasi yang menguntungkan perusahaan (Al-Haddad et al, 2011). Proporsi dividen yang dibayarkan pada pemegang saham tergantung pada kemampuan perusahaan menghasilkan laba serta bentuk kebijakan dividen yang diterapkan oleh perusahaan yang bersangkutan. Prosentase dari laba yang akan dibayarkan kepada pemegang saham sebagai cash dividend disebut Dividend

Payout Ratio (Andriyani, 2008).

Adapun rumusanmasalahdalam penelitian ini adalah: (1) Apakah Debt to Equity Ratio (DER) berpengaruh terhadap Dividen Payout Ratio (DPR) pada perusahaan makanan dan minuman yang terdaftar di Bursa Efek Indonesia periode 2010-2012?; (2) Apakah Current Ratio (CR) berpengaruh terhadap Dividen Payout Ratio (DPR) pada perusahaan makanan dan minuman yang terdaftar di Bursa Efek Indonesia periode 2010-2012?; (3) Apakah Return On Investment (ROI) berpengaruh terhadap Dividen Payout Ratio (DPR) pada perusahaan makanan dan minuman yang terdaftar di Bursa Efek Indonesia priode periode $2010-2012$ ?

\section{REVIEW LITERATUR DAN HIPOTESIS}

\section{Dividen}

Ang (1997) menyatakan bahwa dividen merupakan nilai pendapatan bersih diperusahaan setelah pajak dikurangi dengan laba ditahan (retained earning) yang ditahan sebagai cadangan perusahaan. Dividen ini untuk dibagikan kepada para pemegang saham sebagai keuntungan dari laba perusahaan. Apabila perusahaan penerbit saham mampu menghasilkan laba yang besar maka ada kemungkinan pemegang sahamnya akan menikmati keuntungan dalam bentuk dividen yang besar pula. Penentuan besarnya dana yang dialokasikan untuk pembayaran dividen ini tidak ada yang membatasi, namun tergantung pada Rapat Umum Pemegang Saham (RUPS), apakah laba itu akan dialokasikan untuk pembayaran dividen atau untuk laba ditahan.

Faktor-faktor yang dipertimbangkan dalam memutuskan suatu usulan dividen oleh dewan direksi antara lain: (1) Keuntungan Perseroan; (2) Prospek pertumbuhan usaha; (3) Posisi kas (likuiditas); (4) Aspek hokum; (5) Keadaan pasar.

\section{Teori Kebijakan Dividen}

Menurut Bringham dan Gapenski (1996) ada beberapa teori tentang kebijakan dividen: (1) Bird In the Hand Theory, salah satu asumsi dari teori M-M menyatakan bahwa kebijakan dividen tidak mempengaruhi tingkat keuntungan yang disyaratkan oleh investor. Sementara itu menurut Gordon dan Lintner (1956) tingkat keuntungan yang disyaratkan akan naik apabila pembagian dividen dikurangi, karena investor lebih yakin terhadap penerimaan dividen daripada kenaikan nilai modal (capital gain) yang akan dihasilkan 
dari laba ditahan. Pendapat Gordon dan Lintner (1956) oleh M-M diberi nama Bird in the Hand Fallacy. (2) Tax preference theory adalah suatu teori yang menyatakan bahwa jika capital gain dikenakan pajak dengan tarif lebih rendah daripada pajak atas dividen, maka saham yang memiliki pertumbuhan tinggi menjadi lebih menarik. Tetapi sebaliknya jika capital gain dikenai pajak yang sama dengan pendapatan atas dividen, maka keuntungan capital gain menjadi berkurang. Karena adanya pajak terhadap keuntungan dividen dan capital gain maka para investor lebih menyukai capital gain karena dapat menunda pembayaran pajak.

\section{Dividen Payout Ratio}

Dividend payout ratio (DPR) merupakan persentase pendapatan yang akan dibayarkan kepada pemegang saham sebagai cash dividend. Selain dibagikan dalam bentuk dividen, sebagian dari laba bersih juga akan menjadi laba ditahan. Oleh sebab itu, keputusan mengenai DPR ini akan bertolak belakang dengan keputusan mengenai laba ditahan atau retention ratio decision. Di satu sisi, para pemegang saham akan merasa senang apabila bagian dari laba bersih yang dibagikan sebagai dividen semakin besar. Akan tetapi, apabila DPR ini semakin besar, berarti laba ditahan semakin kecil.

\section{Leverage}

Rasio Leverage dapat diukur dengan debt to equity ratio. Debt to equity ratio merupakan ratio antara total utang (total debt) dengan total aset (total assets) yang dinyatakan dalam persentase. Ratio ini mengukur persentase asset perusahaan yang dibelanjai dengan hutang. Total debt to equity merupakan perbandingan total hutang yang dimiliki perusahaan dengan modal sendiri atau equitas (Martono dan Harjito, 2003).

\section{Likuiditas}

Likuiditas merupakan hal yang penting bagi perusahaan karena dapat mempengaruhi kepercayaan masyarakat. Perusahaan yang kurang mampu dalam memenuhi kewajiban pembayaran tepat pada waktunya akan menyebabkan masyarakat kurang percaya terhadap produktifitas perusahaan secara keseluruhan. Hal ini akan menyebabkan perusahaan semakin sulit untuk memperoleh sumber dana dari investor. Menurut Husnan (1998), ratio likuiditas dapat diukur dengan current ratio.

\section{Profitabilitas}

Sartono (1998) menyatakan profitabilitas adalah kemampuan perusahaan dalam memperoleh laba dalam hubungannya dengan penjualan, total aktiva maupun modal sendiri. Investor jangka panjang akan sangat berkepentingan dengan analisis profitabilitas ini, misalnya bagi pemegang saham akan melihat keuntungan yang benar-benar akan diterima dalam bentuk deviden. Ratio profitabilitas dapat diukur dengan ROI (return On Investment), ratio ini mengukur banyaknya keuntungan yang menjadi hak pemilik modal sendiri.

\section{Hipotesis}

$\mathrm{H}_{1}$ : Debt to Equity Ratio (DER) berpengaruh terhadap Dividen Payout Ratio (DPR) pada perusahaan makanan dan minuman yang terdaftar di Bursa Efek Indonesia.

$\mathrm{H}_{2}$ : Current Ratio (CR) berpengaruh terhadap Dividen Payout Ratio (DPR) pada perusahaan makanan dan minuman yang terdaftar di Bursa Efek Indonesia .

$\mathrm{H}_{3}$ : Return On Investment (ROI) berpengaruh terhadap Dividen Payout Ratio (DPR) pada perusahaan makanan dan minuman yang terdaftar di Bursa Efek Indonesia. 


\section{METODE PENELITIAN}

\section{Populasi, Sampel dan Teknik Pengambilan Sampel}

Populasi dalam penelitian ini adalah perusahaan-perusahaan makanan dan minuman yang terdaftar di Bursa Efek Indonesia periode 2010-2012, yaitu berjumlah 18 perusahaan. Teknik pengambilan sampel yang digunakan dalam penelitian ini adalah purposive sampling dengan tujuan untuk mendapatkan sampel yang sesuai dengan kriteria sebagai berikut: (1) Perusahaan makanan dan minuman yang terdaftar di Bursa Efek Indonesia periode 20102012; (2) Perusahaan makanan dan minuman yang membagikan dividen pada periode 20102012; (3) Memiliki data yang dibutuhkan dalam penelitian pada periode 2010-2012.

Berdasarkan kriteria yang ada, diperoleh sebanyak 10 perusahaan yang memenuhi kriteria untuk dijadikan sampel.

\section{Jenis dan Sumber Data}

Data yang digunakan dalam penelitian ini adalah data sekunder, yaitu data penelitian yang diperoleh secara tidak langsung melalui media perantara (di peroleh dan dicatat oleh pihak lain). Metode pengumpulan data yang digunakan dalam penelitian ini adalah metode Dokumentasi dan data diperoleh dari ICMD (Indonesian Capital Market Directory).

\section{Definisi Operasional Variabel}

Variabel Dependen

Variabel dependen dalam penelitian ini adalah Dividen Payout Ratio. Dividen Payout Ratio menurut Bringham dan Houston (2006) adalah presentase dari laba bersih yang akan dibayarkan sebagai dividen tunai kepada pemegang saham. Jika dividen tunai meningkat maka dana perusahaan untuk reinvestment akan semakin berkurang. Dividen Payout ratio dapat di hitung dengan rumus :

$$
D P R=\frac{D P S}{E P S} \times 100 \%
$$

Dimana:

DPR : Dividend Payout Ratio

DPS : Dividen per lembar saham

EPS : Laba per lembar saham

Variabel Independen

a. Debt to Equity Ratio $\left(\mathrm{X}_{1}\right)$

Debt to Equity Ratio merupakan ratio antara total utang (total debt) dengan total aset (total assets) yang dinyatakan dalam persentase. Ratio ini mengukur persentase asset perusahaan yang dibelanjai dengan hutang. Total debt to equity merupakan perbandingan total hutang yang memiliki perusahaan dengan modal sendiri atau equitas (Martono dan Harjito,2003). Rumus yang digunakan dalam penelitian ini dirumuskan sebagai berikut :

$$
D E R=\frac{\text { Total kewajiban }}{\text { Total Modal Sendiri }} \times 100 \%
$$

\section{b. Current Ratio $\left(X_{2}\right)$}

Likuiditas adalah kemampuan perusahaan untuk memenuhi kewajiban-kewajiban jangka pendek. Dalam ratio ini peneliti menggunakan ratio Current Ratio. Rumus yang digunakan dalam penelitian ini dirumuskan sebagai berikut:

$$
\text { Current Rasio }=\frac{\text { Aktiva Lancar }}{\text { Hutang Lancar }} \times 100 \%
$$

\section{c. Return on Investment $\left(\mathrm{X}_{3}\right)$}

Profitabilitas adalah tingkat keuntungan bersih yang berhasil diperoleh perusahaan dalam menjalankan operasinya. Dalam penelitian ini peneliti menggunakan ratio Return OnInvestment. Rumus yang di gunakan dalam penelitian ini di peroleh dari penelitian terdahulu yaitu sebagai berikut :

$$
R O I=\frac{\text { Earning After Tax }}{\text { Total Aktiva }} \times 100 \%
$$




\section{HASIL PENELITIAN DAN PEMBAHASAN}

\section{Analisis Data}

Uji Regresi Data Panel

Berdasarkan hasil analisis regresi data panel dalam penelitian ini diperoleh hasil sebagai berikut:

Tabel 1

Hasil Uji Regresi Data Panel

\begin{tabular}{|c|c|}
\hline Variabel & Coefficient \\
\hline C & 17.81471 \\
\hline DER? & -11.27266 \\
\hline CR? & 11.98046 \\
\hline ROI? & 0.034947 \\
\hline
\end{tabular}

Sumber: Data diolah, 2014

Dari hasil di atas, maka dapat disusun persamaan regresi sebagai berikut:

$\mathrm{DPR}=17.81471-11.27266 \mathrm{DER}+11.98046 \mathrm{CR}$ $+0.034947 \mathrm{ROI}+e$

Nilai konstanta sebesar 17.81471 dapat diartikan bahwa jika variabel DER, CR, ROI, adalah nol maka nilai Dividen Payout Ratio pada perusahaan makanan dan minuman akan sama dengan nilai konstanta yaitu sebesar 17.81471.

Koefisien regresi DER sebesar -11.27266, berarti bahwa setiap penurunan satu nilai dari DER maka akan memberikan kenaikan dividen payout ratio pada perusahaan makanan dan minuman sebesar 11.27266 poin. Sebaliknya setiap kenaikan satu nilai dari DER maka akan memberikan penurunan dividen payout ratio pada perusahaan makanan dan minuman sebesar 11.27266 poin.

Koefisien regresi CR sebesar 11.98046 , berarti bahwa setiap kenaikan satu nilai dari CR maka akan memberikan kenaikan dividen payout ratio pada perusahaan makanan dan minuman sebesar 11.98046 poin. Sebaliknya setiap penurunan satu nilai dari CR maka akan memberikan penurunan dividen payout ratio pada perusahaan makanan dan minuman sebesar

\subsection{6 poin.}

Koefisien regresi ROI sebesar 0.034947 , berarti bahwa setiap kenaikan satu niai dari ROI maka memberikan kenaikan dividen payout ratio pada perusahaan makanan dan minuman sebesar 0.034947 poin. Sebaliknya setiap penurunan satu nilai dari ROI maka akan memberikan penurunan dividen payout ratio pada perusahaan makanan dan minuman sebesar 0.034947 poin. Uji $t$

Uji $t$ digunakan untuk mengetahui pengaruh variabel independen secara parsial atau sendiri-sendiri terhadap variabel dependen. Hasil uji t dapat dilihat pada tabel berikut ini:

Tabel 2

Hasil Uji t

\begin{tabular}{|c|c|}
\hline Variabel & Prob. \\
\hline DER? & 0.2555 \\
\hline CR? & 0.0487 \\
\hline ROI? & 0.9584 \\
\hline
\end{tabular}

Sumber: Data diolah, 2014

Pengujian parsial terhadap variabel debt to equity ratio (DER) menunjukkan nilai signifikan hitung sebesar 0.2555 . Karena angka tersebut lebih besar dari angka signifikan 0.05 yang merupakan angka derajat kepercayaan, $\mathrm{H}_{1}$ ditolak atau dapat disimpulkan bahwa tidak ada pengaruh yang signifikan dari debt to equity ratio terhadap dividen payout ratio.

Variabel current ratio (CR) menunjukkan nilai signifikan hitung sebesar 0.0487 . Nilai tersebut lebih kecil dari nilai signifikan 0.05 yang merupakan angka derajat kepercayaan, maka $\mathrm{H}_{2}$ diterima atau dapat disimpulkan bahwa ada pengaruh yang signifikan dari current ratio terhadap dividen payout ratio.

Variabel return on investment (ROI) menunjukkan nilai signifikan hitung sebesar 0.9584 . Nilai tersebut lebih besar dari nilai signifikan 0.05 yang merupakan angka derajat kepercayaan, maka $\mathrm{H}_{3}$ ditolak atau dapat disimpulkan bahwa tidak ada pengaruh yang 
signifikan dari return on investment terhadap dividen payout ratio.

\section{Uji Koefisien Determinasi $\left(\mathrm{R}^{2}\right)$}

Koefisien determinasi $\left(R^{2}\right)$ pada intinya mengukur seberapa jauh kemampuan model regresi dalam menerapkan varian variabel dependennya. Nilai $R^{2}$ yang mendekati satu berarti variabel-variabel independennya memberikan hampir semua informasi yang dibutuhkan untuk memprediksi variasi variabel dependen ( ghozali, 2006).

\section{Tabel 3}

Hasil Uji Koefisien Determinasi

\begin{tabular}{|l|c|}
\hline $\mathrm{R}^{2}$ & 0.385 \\
\hline \multicolumn{2}{|c|}{ Sumber: Data diolah, 2014} \\
\hline
\end{tabular}

Berdasarkan table 3 tampak bahwa dari hasil perhitungan diperoleh nilai koefisien determinasi $\left(R^{2}\right)$ sebesar 0.385. Hal ini menunjukkan bahwa variabel independen DER, CR dan ROI mampu mempengaruhi perubahan variabel dependen yaitu DPR sebesar $38.5 \%$ dan sisanya sebesar $61.5 \%$ dipengaruhi oleh variabel lain di luar variabel yang digunakan dalam penelitian.

\section{Pembahasan}

Adapun informasi yang diperoleh dari dalam penelitian ini adalah pada variabel $d e b t$ to equity ratio (DER) tanda negatif koefisien regresinya menunjukkan bahwa apabila DER menurun maka dividen payout ratio (DPR) meningkat. Hasil penelitian menunjukkan bahwa pengaruh negatif variabel DER terhadap DPR menjelaskan bahwa semakin rendah tingkat kemampuan perusahaan dalam memenuhi kewajibannya maka akan berdampak pada peningkatan pembagian dividen yang dilakukan perusahaan.

Pada variabel current ratio (CR), tanda positif koefisien regresinya menunjukkan bahwa apabila CR meningkat maka DPR juga meningkat. Hasil penelitian menunjukkan bahwa pengaruh positif variabel CR terhadap DPR menjelaskan bahwa semakin kuat tingkat kemampuan perusahaan dalam memenuhi kewajibannya maka akan berdampak pada peningkatan pembagian dividen yang dilakukan perusahaan.

Pada variabel return on investment (ROI), tanda positif koefisien regresinya menunjukkan bahwa apabila ROI meningkat maka DPR juga meningkat. Hasil penelitian menunjukkan bahwa pengaruh positif variabel ROI terhadap DPR menjelaskan bahwa semakin kuat tingkat kemampuan perusahaan dalam memenuhi kewajibannya maka akan berdampak pada peningkatan pembagian dividen yang dilakukan perusahaan.

\section{KESIMPULAN DAN SARAN}

Berdasarkan hasil penelitian maka disimpulkan bahwa variabel Debt to Equity Ratio dan Return On Investment tidak berpengaruh signifikan terhadap Dividen Payout Ratio, sedangkan variabel Current Ratio berpengaruh signifikan terhadap Divident Payout Ratio.

Saran bagi investor yang ingin berinvestasi dalam bentuk saham dan menyukai keuntungan dari pembagian dividen dapat menggunakan Debt to Equty Ratio, Current Ratio dan Return On Investment untuk memprediksi kemampuan emiten untuk membagikan dividen.

Bagi peneliti selanjutnya, disarankan untuk menggunakan data dalam kurun waktu yang lebih lama, misalnya lima tahun terakhir serta menggunakan rasio keungan yang lebih banyak.

\section{DAFTAR PUSTAKA}

Ang, Robert. 1997. Buku Pintar Pasar Modal Indonesia. Jakarta: Mediasoft Indonesia.

Brigham, E.F dan L.C Gapensky. 1996. Internasional Finansial manajerial. Sixth Edision, New York: The Dryden Prees. 
Damayanti, S. \& Achyani, F. (2006). Analisis pengaruh investasi, liquiditas, profitabilitas, pertumbuhan perusahaan dan ukuran perusahaan terhadap kebijakan dividen payout ratio (Studi empiris pada perusahaan manufaktur yang terdaftar di BEJ). Jurnal Akuntansi dan Keuangan 5 (1), April 2006. Surakarta: Universitas Muhammadyah Surakarta..

Dermawan E.S. 1997. Faktor-fektor Penentu Kebijakan Pembayaran Tahun 1994. Tesis. UGM

Gujarati, Damodar N. 2006. Ekonometrika Dasar. Jakarta : Penerbit Erlangga.

Gujarati dan Porter. 2009. Dasar-Dasar Ekonometrika. Jakarta: Salemba Empat

Hadiwijaja et al,. 2009. Pengaruh Profitabilitas Terhadap Dividen Payout Ratio Pada Perusahaan Manufaktur Di Indonesia. Jurnal Organisasi Dan Manajemen. Hal49-54.

Hanafi, Mamduh. 2004. Manaemẹn Keuangan. Cetakan Pertama, BPFE: Yogyakarta.
Husnan, S. 1988. Manajemen Keuangan, Keputusan investasi dan Pembelanjaan Edisi 2. Yogyakarta BPFE UGM .

Joyanto. 1998. Teori portofolio dan analisis investasi. edisi pertama. Yogyakarta: BPFE UGM

Munawir, S. 2001. Analisis Laporan Keuangan. Yogyakarta: Liberty.

Nasrul, I.H. 2004. Analisis faktor-faktor yang mempengaruhi Divident payout ratio pada perusahaan manufaktur go-pablik di bursa efek Indonesia. Tesis. USU. Medan. (tidak dipublikasikan)

Prastowo, Dwi. 2011. Analisis laporan keuangan. Yogyakarta: UPP STIM YKPN..

Riyanto, B. 1995. Dasar-Dasar Pembelanjaan Perusahaan. Edisi Keempat, BPFE UGM.

Weston, Freed dan Thomas, E coopeland. 1996. Manajemen Keuangan. Jakarta: Erlangga.

Widiatmoko, Harisya. 2013. Analisis pengaruh Cash Position, Debt to Equity Ratio, Return OnAssetterhadap Dividen Payout Ratio pada perusahaan manufaktur yang terdaftar di BEI. Skripsi. Yogyakarta: Universitas Ahmad Dahlan. 